City University of New York (CUNY) CUNY Academic Works

2015

"The Problem of Locomotion": Infrastructure and Automobility in Three Postcolonial Urban Nigerian Novels

Danica B. Savonick

The Graduate Center, CUNY

How does access to this work benefit you? Let us know!

More information about this work at: https://academicworks.cuny.edu/gc_studentpubs/23

Discover additional works at: https://academicworks.cuny.edu

This work is made publicly available by the City University of New York (CUNY).

Contact: AcademicWorks@cuny.edu 
"THE PROBLEM OF LOCOMOTION":

INFRASTRUCTURE AND

AUTOMOBILITY IN THREE

POSTCOLONIAL URBAN

NIGERIAN NOVELS

\section{Danica Savonick}

He dashed across a major road and was missed by a huge red bus by a hair's breadth. He backed, went forward, turned right and left like a panicky fly trapped behind the windscreen. Cyclists and pedestrians cursed him. At one stage the whole of Lagos rose in one loud protest: "ONE WAY! ONE WAY!!" He stopped, backed into a side street, and then went in the opposite direction.

-Chinua Achebe, No Longer at Ease

Gleaming cars-BMWs, Lexus's [sic]-line the waterfront, spilling out young people giddy with money and power and privilege and sunshine. All of this belies the executions that used to happen here in the '70s.

-Chris Abani, "Lagos: A Pilgrimage in Notations" 
Although automobile accidents are common tropes in novels that take place in Lagos-marking the embodied expenses of colonial modernization-it is no accident that Chinua Achebe's No Longer at Ease opens with "the problem of locomotion" (2) and the disjuncture between automobility and its infrastructural conditions of impossibility. Automobility names the fantasy of self-propulsion that subtends a colonial modernity materialized through urbanization. However, in postcolonial urban Nigerian novels the fantasy of automobility runs up against its infrastructural impossibility: the roads, erected under colonial rule, were not designed to facilitate the movement of Nigerians. Despite this, as Brian Larkin argues, they were ideologically appropriated as the fulfillment of colonialism's promised progress and used to legitimize colonial rule (43). The construction of infrastructural provisions in and around Lagos had "its roots in the civilizing mission of colonial development and its potential for modernizing colonial subjects" (7). In effect, colonialism erected a Nigeria in its image, orchestrated through infrastructure as a form of indirect rule. Achebe's protagonist, Obi Okonkwo, experiences colonial infrastructure as an impasse as he attempts to enact modernity's fantasy of automobile self-propulsion, driving his recently acquired Morris Oxford the wrong direction down a street marked "ONE WAY" (170). ${ }^{1}$ This disjuncture between automobility and infrastructural possibility features prominently in two later postcolonial novels, Chris Abani's GraceLand and Chika Unigwe's On Black Sisters Street, illustrating how colonial power arrangements continue to haunt Lagos into the late twentieth and early twenty-first centuries. ${ }^{2}$ Tracing the problem of locomotion - the fantasy of automobility foreclosed by infrastructural conditions of impossibility-throughout these novels reveals the inextricability of mobility, modernity, urbanism, and the violence of colonialism with Nigeria's formally postcolonial period.

Infrastructuralism focalizes the inherited, officially carved paths, though these novels also explore alternative trails of desire: the shortcuts, trampled footpaths, and meandering byways that trace and leave traces of alternative dérives (a term used in psychogeography to designate unplanned, unofficial journeys through a landscape). An infrastructural optic allows one to observe the sway of the past in the present through examples of inherited collective investments. However, focusing solely on infrastructural elements can also downplay a novel's engagement with other political, philosophical, and affective concerns. To avoid this, I supplement a purely infrastructural perspective with a consideration of characters' investments in modern urban automobility-the fantasy that regardless of where one comes from, the good life can be obtained in the city. ${ }^{3}$ 
Paul Gilroy's analysis of African Americans' investments in automotive culture raises the "provocative possibility . . . that a distinctive history of propertylessness and material deprivation may have inclined African Americans towards a disproportionate investment in particular forms of property that are publicly visible and in the status that corresponds to them" (20-21). Gilroy's analysis of mobility in the context of the United States is underscored by Raymond Williams's argument, summarized by Gilroy, that automobile culture in Britain was characterized by "the increased privatisation of life and its fragmentation into active, small-family units . . . combined with an unprecedented degree of mobility" (24). Although the fantasies of cars in these urban Nigerian novels similarly suggest that an uneven history of ownership corresponds to an increased investment in an automobile's hypervisibility, Nigeria's independence from British colonial rule and emergence into global networks of consumption and production did not coincide with significant wealth redistribution, or result in "an unprecedented degree of mobility." Despite the privatization evident in automobile fantasies, material inequality was exacerbated in the period in which these novels are set. These differences among British, US, and Nigerian histories signal the need to translate rather than transplant Gilroy's work in order to understand how automotive fantasies of luxury cars offer protagonists a means of participating in privatization.

By suturing this modern fantasy of self-propulsion to the danger of the highways, these novels expand on Abani's observation that the prospect of "gleaming" foreign cars "belies" material and political violence (4). Indeed, cars provide an important counterpoint to the commonly felt experience of precarity on the haunted highways. Reading the representations of cars in these novels through Gilroy's understanding of the privatizing logic that animates automobile culture suggests that the fantasy of "individualised automotivity" (13) must be understood not only as a way of participating in consumer capitalism but also as a desire for automotive self-determination, a break from colonial domination.

\section{Urban Disenchantment in Chinua Achebe's No Longer at Ease}

Published on the brink of Nigerian independence in 1960 and set in the decades immediately preceding it, No Longer at Ease begins and ends with the bribery trial of Obi Okonkwo, a young man from the village Umuofia who was sent to university in England and returned to a civil service job in Lagos as Secretary to the Scholarship Board. The 
novel moves between Obi's present in Lagos as an African "pioneer" (86) trying to navigate through this upper-class, European world and his past in Umuofia and England, both of which led him to this prestigious position. Whereas the first half of the novel is filled with the glamour of moving to the city, purchasing a car, and proposing to his girlfriend Clara, all this unravels in the novel's second half as unforeseen expenses (petroleum, insurance, electricity bills, income tax, an abortion, and so forth) alienate Obi from Clara, his friends, colleagues, and fellow Umuofians. In contrast to the city of "electric lights and motorcars" (15) that once sparkled in his imagination, Obi becomes disenchanted through his discoveries of the unaffordable price of life in "the real Lagos" (18).

During Nigeria's colonial period, officially from 1900 to 1960 , Lagos developed into a modern city. The British colonial government designated it a first-class township because its proximity to the ocean made it an ideal location for transporting extracted resources back to the metropole (Abumere 266-67). In Achebe's novel, the urban seduction of life in a modern city transforms into disenchantment through images of electric lights and motorcars, symbols of colonial infrastructures. Returning to Lagos after studying in London, Obi and his friend Joseph go to a restaurant in which Obi observes the lighting fixtures: "Soft light came from large globes around which insects danced furiously. Perhaps they did not notice that each globe carried a large number of bodies which, like themselves, had danced once upon a time. Or if they noticed, they did not care" (38). The bright allure of Lagos-a space of increased velocity, heightened movement, and automobility-is juxtaposed with the embodied violence of life in a colonial city. Lagos brings Obi closer to British colonialists, whose shiny imports of electricity and motorcars obscure the practices of resource extraction that divert oil-the would-be lifeblood of the Nigerian people-back to the colonial metropole. ${ }^{4}$

Obi's trajectory exemplifies the fantasy of modern urban automobility. The novel introduces a narrative path that indicates an investment in colonial promises of progress and modernization and a desire to share in the wealth allegedly evidenced by the presence of electricity, running water, roads, railways, and bridges. Specifically, it is the fantasy that a good (English) education will lead to a government job, wealth, a foreign car, and prosperity: "A university degree was the philosopher's stone. It transmuted a third-class clerk on one hundred and fifty a year into a senior civil servant on five hundred and seventy, with car and luxuriously furnished quarters at nominal rent" (105). There is something magical about this urban promise; it offers a shortcut that will "transmute" a Umuofian into a modern European, without the hard work of rural life: "We left plenty of work 
at home. . . . Anyone who likes work can return home, take up his matchet and go into that bad bush between Umuofia and Mbaino" (91). In contrast to this colonial promise of education as the magical means to a glamorous urban lifestyle and wealth without work, Obi's experiences in Lagos "dulled his sensibility and left him a different man, able to look words like education and promise squarely in the face" (3).

The difficulties of being Umuofia's first pioneer of urban modernity emerge through problems of velocity and, primarily, lateness. The novel opens with the judge of Obi's trial, Justice William Galloway, responding to the lateness of a counsel member, Mr. Adeyemi. After Mr. Adeyemi apologizes for his car breaking down, an early example of the forestalled automobility that Obi will experience, Justice Galloway complains of being "sick and tired of these constant excuses about the problem of locomotion" (2). Although we initially see Mr. Adeyemi as stammering, embarrassed, and apologetic, the novel gradually reveals the role of colonial power relations in orchestrating these conditions that make it appear as if an African civil servant, by his own incapacity, is lagging behind his British colonial boss. Another example of asynchronicity occurs at a prayer meeting before Obi goes abroad. He is cautioned not to "be in a hurry to rush into the pleasures of the world like the young antelope who danced herself lame when the main dance was yet to come" (12). These problems of locomotion-of moving too fast or not fast enough-crystallize around Obi's car, a shiny Morris Oxford. As Byron Caminero-Santangelo argues, imported British-made cars like the Morris Oxford further entrenched colonial economic relations by diverting Nigerian wealth back to the colonial metropole (41-42). The small group of wealthy Nigerians who owned these foreign luxury cars were more willing to collaborate with the British, which helped ensure that this unilateral flow of capital would continue even into Nigeria's formally postcolonial period.

Whereas the characters in No Longer at Ease treat Obi's car as a symbol of the good life, the very car that promises contagious happiness almost immediately precipitates a sequence of most unhappy events. The car, ostensibly a sign of economic achievement, quickly loses its referentiality as the wealth to which it alludes never materializes. In addition to the unanticipated expenses of vehicle ownership-including gas and insurance-the success implied by his car obligates Obi to pay out money to his family and village, who taxed themselves relentlessly to send Obi to university. Obi is acutely aware that belonging to the upper class depends on his car: "Having made him a member of an exclusive club whose members greet one another with 'How's the car behaving?' did they expect him to turn round and answer: 'I'm sorry, but my car is off the road. You see, I 
couldn't pay my insurance premium'? That would be letting the side down in a way that was quite unthinkable" (113). As the first of his village to obtain a government job previously held by Europeans, Obi is not forewarned about the externalities of affluence and conspicuous consumption. Nor is he able to "let the side down" and break with the infrastructural fantasy of automobility subtended by imperial power relations. He does not, like the protagonist of Ralph Ellison's "Cadillac Flambé," detach from the fantasy of automobility by staging an immolation "to sacrifice his well-appointed vehicle in a spectacular act of political theater" (Gilroy 18). Instead, his failed attempts to adopt this debt-fueled lifestyle lead to his imprisonment, foreclosing the automotive promise of his Morris Oxford.

The roads between Umuofia and Lagos stage this foreclosure of automobility. During his journey from Lagos back to Umuofia in a mammy wagon, Obi unintentionally bears witness to an illicit exchange between the driver and police, an observation that ends up costing the driver more money: "It was only some minutes later that Obi realized why they had stopped. The driver's mate had run back to the policemen, knowing that they would be more amenable when there were no embarrassing strangers gazing at them" (50). The driver then turns his anger to Obi, "who was already beginning to feel a little guilty, especially as all the traders behind . . . had switched their attacks from career girls to 'too know' young men." Instead of the mobility that his education is supposed to enable, Obi's English university degree makes him a "too know" young man, an "embarrassing stranger" whose gaze offends the policeman, exacerbating the cost of the bribe and prolonging the journey's duration. Rather than increasing the ease with which Obi moves through Nigeria, his European education-part and parcel of the colonial fantasy of urban prosperity-slows everyone down.

Later, while on another five-hundred-mile trip between Lagos and Umuofia, Obi drives alone in his Morris Oxford, enacting what should be the happy fantasy of automobility. Instead, he "numbly" drives in a "daze" (159) - an affective embodiment of the life-denying history of the Nigerian roads. "Only once did the journey come alive," writes Achebe, when Obi is run off of the road, narrowly skirting a deadly collision with an oncoming lorry. Ironically it is a near-death encounter that breathes life into his journey, which anticipates the close proximity and rapid oscillations between life and death that characterize the highways, especially in the two more recent postcolonial novels. These affects of infrastructure-guilt and numbness-index what it feels like for a postcolonial protagonist trying to materialize the false colonial promises of urban mobility. 
The urban disenchantment of No Longer at Ease can be understood as a response to a history in which British colonial rule erected a Nigeria in its image, orchestrated through both material infrastructures and affective fantasies of the good life as forms of indirect rule. The novel suggests that to believe in the simplicity and ease with which Obi "walked into the shop and got a brand-new car" (76) is naive given the colonial conditions that produced this fantasy. To buy into the fantasies that emerged from such antagonistic conditions is to drive the wrong way down a one-way street. Indeed, Obi's automobile fantasy reaches an impasse as his attempts to traverse the infrastructural pathways (or lack thereof) carved by colonialism leave him incarcerated and immobilized.

\section{American Automobility in Chris Abani's GraceLand}

In many ways, GraceLand directly responds to the impossibility of materializing automobile fantasies in No Longer at Ease. Whereas Obi offhandedly remarks that "real tragedy is never resolved" (40), the narrator of GraceLand responds that "[n]othing is ever resolved. . . . It just changes" (320). Although Lagos and the fantasy of urban automobility have changed, "the problem of locomotion" remains unresolved as colonial violence haunts the novel's present through Nigeria's embeddedness within the global oil economy. ${ }^{5}$ Between the publication of Achebe's and Abani's novels, Nigeria became independent, a transition that was unaccompanied by wealth redistribution. Whereas Achebe's earlier novel dramatizes Obi's failed attempts to pioneer a European post in Lagos given the structural antagonism of British policies of indirect rule, the two later novels foreground the effects of Lagos's increasing inequality in the late twentieth and early twenty-first centuries, partially the result of global economic policies of structural adjustment and oil extraction by foreign companies. During the early 1970s, a sudden rise in oil prices provided funds for an ambitious road-building program, which contributed to the growth of urban centers. Foreign petroleum companies like Shell-BP and Mobil invested in the construction of Nigeria's infrastructure to facilitate the exportation of the country's oil wealth (Mba 7). It was this oil boom that initially created jobs and literally paved the way for migration to Nigeria's largest city, though when this bubble burst, the population of Lagos continued to blossom without concurrent growth of employment opportunities (Davis 15). This urban migration brings the protagonist of GraceLand, Elvis Oke, to Lagos.

GraceLand maps the paths and possibilities available to Elvis, a poor slum-dweller living through the oil boom of the 1970 s and bust 
of the early 1980s. Elvis's father, Sunday, moves the family to Lagos after his political ambitions are thwarted by corruption in Afikpo. Like Achebe's novel, the first part of GraceLand oscillates spatially and temporally between Elvis's urban present and his small-town past. However, because Elvis's family is forced to move from Afikpo to Lagos's Maroko slum, the city is far less seductive in Abani's novel, leaving little room for disenchantment. The vibrant city of electric lights and motorcars that tempted Obi twenty years earlier is now symbolized by a "naked lightbulb. . . . Insects were buzzing around it even though it was losing its power" (109). Echoing Achebe's glowing globe, Abani's lightbulb similarly illuminates the false promise of urban allure, though its nakedness foreshadows the corporeal vulnerability of the novel's characters, who experience urban violence more viscerally than Obi. Whereas Obi worries about keeping up appearances, the characters in GraceLand worry about where their next meal will come from. Unlike his alcoholic father who experiences Lagos through a drunken haze, Elvis sees the city as "half slum, half paradise," and he wonders, "How could a place be so ugly and violent yet beautiful at the same time?" (7). The second part of the novel moves chronologically through a series of events in 1983, including Sunday's failed attempts to defend Maroko against a slum clearance, Elvis's unintentional participation in a human trafficking scheme, his time spent on the road as a performer, his torture and incarceration, a violent confrontation between a military general and a grassroots organizer, a biblical flood during Elvis's brief stint living in "Bridge City," and his impending departure for America.

Elvis's poverty leaves him unburdened by the social responsibilities and expectations that weigh so heavily on Obi. Whereas Obi is immobilized by his failed attempts to occupy a European post, Elvis's freedom from having to follow the path of education toward a government job and car allows him to explore other avenues. After dropping out of school-detaching from the inherited fantasy that "education is de only chance here" (165)-Elvis attempts to work as a day laborer and escort. These failed employments give him firsthand knowledge of how difficult it is to materialize the good life in Lagos: "Most people just want to work hard, earn a living and find some entertainment. Yet it seems that no matter how they try, they remain poor" (280). Given this impossibility that hard work will result in even a modest version of the good life, Elvis and his friend Redemption experiment with riskier ventures (trafficking cocaine and humans) that seemingly offer shortcuts to wealth. ${ }^{6}$ Rather than trying to procure a steady job and lawfully purchase a car, Redemption steals a Mercedes, which the two use to escape after finding out that they have been facilitating a human trafficking scheme. The 
danger of refusing to follow inherited infrastructures is evident in a motorcycle ride, during which Redemption attempts to circumvent a police checkpoint by hurtling across five lanes of traffic, leaving Elvis "[w]ounded, but not dead" (194). The novel neither punishes nor romanticizes these enactments of automobility; instead, it depicts them as precarious shortcuts to prosperity, attempts to circumvent the crumbling colonial infrastructures.

Similar to No Longer at Ease, in GraceLand, luxury cars symbolize the desire for automobility, an unattainable aspiration within the conditions of the novel's present (1974-83). Yet while Achebe's novel dramatizes the problem of locomotion through infrastructures of British colonial rule and a British-made Morris Oxford, in GraceLand, the impossible fantasy of automobility is intertwined with the United States: both the promised land of Ford Mustangs and perpetrator of violence against Nigerians. Rather than gradually revealing the impossibility of the automotive fantasy, GraceLand announces it from the beginning, opening in Elvis's bedroom in which a "magazine cutting of a BMW was coming off the far wall, its end flapping mockingly" (4). This fraying fantasy of a BMW is replaced by a Ford Mustang, an American car that features prominently in the Western films Elvis and his friends revere. Elvis is a character who both impersonates and was named after the American pop icon and car enthusiast. A scene between him and Redemption demonstrates the global circulation of American automotive fantasies within transnational imaginative economies. According to Redemption, who fuels Elvis's American fantasies, "States is de place where dreams come true, not like dis Lagos dat betray your dreams. . . . Dese gangsters drive 1965 Ford Mustangs, you see. Like cowboys" (26). When Elvis objects, "I thought cowboys rode horses?" Redemption responds, "De horse is dere, on de hood of de Mustang. Same thing." This exchange marks a shift away from Lagos as a city of colonial promise toward the United States. It illustrates how global capital works affectively, circulating desires for Western commodities through Hollywood films that layer cowboy culture's masculinist and imperial frontier fantasies into cars, symbols of unfettered automobility and the American dream. In addition to depicting the politics of resistance to the structural inequality of global capital as Ashley Dawson and Ian Munro have argued, the novel's portrayal of automobility foregrounds how the transnational circulation of cultural fantasies binds these postcolonial characters to a system of economic dispossession.

The novel acknowledges how the United States (in conjunction with the IMF and the World Bank) foreclosed the very fantasy that it seemed to make available: "De majority of our people are honest, hardworking people. But dey are at de mercy of dese army bastards 
and dose tiefs in the IMF, de World Bank and de US" (280). The King of Beggars uses a hypothetical narrative of infrastructure-the construction of "potable and clean water supply" in rural areas-to condemn the IMF's lending policies that profit Americans and leave Nigerians "ow[ing] de World Bank ten million dollars for nothing" (280). ${ }^{7}$ Indeed, Mike Davis reads this angry accusation as a reflection of the anti-IMF student protests that took place in Lagos in 1989 (162-63). Following this lesson in collective injustice, Elvis acknowledges the need for political change given the impossibility of materializing even the modest fantasy that hard work will produce a living wage.

In contrast to fantasies of Ford Mustangs, the molues Elvis actually travels in exemplify the material afterlife of globalization:

Molues were buses unique to Lagos, and only that place could have devised such a hybrid vehicle, its "magic" the only thing keeping it from falling apart. The cab of the bus was imported from Britain, one of the Bedford series. The chassis of the body came from surplus Japanese army trucks trashed after the Second World War. The body of the coach was built from scraps of broken cars and discarded roofing sheets-anything that could be beaten into shape or otherwise fashioned. (8-9)

Elvis and his friends experience globalization through scraps and refuse, the detritus of world wars devoid of the auratic glamour surrounding luxury cars. Instead of driving themselves around (auto-mobility), they travel together in molues, whose colloquial nicknames-"flying coffins" and "moving morgues" (Davis 132)-indicate the embodied risk of movement through Lagos. Given the rapid population growth in cities like Lagos, despite the lack of sufficient housing and job opportunities, the streets these molues traverse are both economic spaces and stages on which life and death occur for many of the world's inhabitants-depicted in GraceLand as both violent and haunted.

The highways in GraceLand - "crossroads of the living and dead" (4)-both fuel and foreclose the characters' markedly American fantasies of automobility. The deadliness of the roads invokes their colonial construction, the neocolonial exploitation perpetuated by the oil economy, and the necronomics of life on the streets. In contrast to survivalist rhetoric of Lagos's "vibrant . . . Do It Yourself" informal economy (Otchet 22-23) -a thinly veiled celebration of neoliberal flexibility and individual resilience-necronomics foregrounds how these circuits of exchange monetize the value of human life and produce conditions in which the death of many yields a profit for the few. In one example, an exploded petrol tank causes a traffic jam 
and a fire that rages as firefighters stand idly by. The conflagration, "too big for them to fight" (179), alludes to the systemic nature of the oil economy and its embeddedness within global economic relations. Because they cannot extinguish this fire, the urban crowd enacts a symbolic form of retribution through the burning of tires, both a product of petroleum and a commodity that ought to enable the fantasy of automobility. The oil industry is indicted through multiple scenes of vigilante justice in which a "necklace of fire-a tire around the neck doused with petrol and set on fire" (30), is used to "baptize" (227) those who the crowds deem thieves, stand-ins for the theft of Nigerian oil wealth. ${ }^{8}$ This use of religious language to describe theft suggests that money is the shared religion that unites Nigeria's diverse people, both literally, since currency (the naira) is one of the few things common to Lagos's distinct populations, and spiritually, as it is the "esprit de corps" (Abani 234) that mediates a potentially hostile encounter between Elvis, Redemption, and the police, reminiscent of the highway bribery scene in No Longer at Ease. In doing so, the novel expresses a strong anxiety that this form of money-worship, integral to Lagos's informal economy, too easily places a price tag on human life.

Whereas Andrew Apter figures oil money as the lifeblood of Nigeria's petrostate, the deadly roads in these novels dramatize the inverse necronomic conversion of blood into oil money. ${ }^{9}$ Elvis is disturbed by the pedestrians who cross the dangerous roads despite the bridges designed to facilitate the safe navigation of urban space: although "life in Lagos is a gamble . . . why not even the odds a little?" (57). The novel offers no explanation for this rejection of infrastructure, which Elvis understands as also a refusal of "logic." While Dawson reads this "irrationality" as "a kind of world-weary resignation to fate and mortality" (22), it could also suggest a dangerous, embodied refusal to traverse the paths carved out by an otherwise ignorant government that has exacerbated conditions of material inequality. Not only have the ambulances that would come for these bodies been hired out as taxis, they also serve as hearses for funeral processions, commemorating the wealthy dead instead of saving the lives of the poor. It is on these corpse-strewn highways that Lagos's infamous traffic jams intersect with the trafficking of human bodies, as Redemption and Elvis get caught up in a trafficking scheme that culminates in human heads rolling out of the trunk of a van. ${ }^{10}$ Furthermore, Elvis's friend Okon lives on the streets and sells his blood in order to eat, dramatizing how the actual blood of the urban poor is a substitute for the resources extracted and sent elsewhere by the oil economy. Okon articulates the fine moral line between harvesting organs from human roadkill and murder: "It is bad for a man's soul, 
waiting at roadside like vulture, for someone to die, so you can steal fresh corpse, but man must survive. When dey start to demand alive people, me I quit. I am not murderer. Hustler? Survivor? Yes. But definitely not a murderer" (308). Unlike the oil tycoons or the Colonel, a ruthless assassin who orchestrates kidnappings and sells organs to wealthy American hospitals and "rich white people" (242) by way of Saudi Arabia, Okon refuses to profit on murder. These intersections between human trafficking and the oil economy illustrate how both are means through which the global political elite profit on the death of Nigerians-the price of oil that enables automobility, whether in Lagos or New York City.

In GraceLand, the crumbling highways abandoned by the government following the oil boom are haunted by spirits who refuse to merely commemorate Nigeria's violent history of colonization: "An old man on the bus had told him that the spirits of the road danced around the buses trying to pluck plump offerings, retribution for the sacrilege of the road, which apparently, when it was built, had severed them from their roots, leaving them trapped in an urban chaos that was frightening and confusing" (9). These melancholy spirits that live in "frightening and confusing" chaos neither memorialize nor pave over Lagos's colonial history; instead, they layer histories of colonial violence into contemporary infrastructures. ${ }^{11}$ An example of these street spirits in Yoruba theology is Ogun, the vengeful orisha of the roads, whose existence rejects the flattening out of history implicit in a unilateral narrative of colonial modernization. Instead of a strict dichotomy between African tradition and European modernity, the spirits of the road reveal the city as a space of hybridity in which the "post" of the postcolonial carries with it the legacy and afterlife of colonialism.

These haunted highways are integral to Abani's mapping of Lagos as a city "of the melancholic soul . . . [a place] of real joy, of concrete despair and of inventiveness" ("Lagos" 2). The novel avoids reducing the complexity of life in postcolonial Lagos to the Afropessimism of a blood oil narrative through Elvis's experimental ethos and his movement through the city-despite its inhospitable infrastructures. ${ }^{12}$ Throughout the novel, Elvis experiments with gender, sexuality, and lifestyle, carving out new possibilities where none seem to exist. He is an artist of the self, accused of "inventing de world" (170) and repeatedly reminded by his friends that "[d]is is not a movie" (194). He sexually experiments with his young male friends, performs for tourists as an Elvis Presley impersonator, and tries on makeup, refusing the narrow patriarchal codes of masculinity he inherits from his father. "You don't understand de difficulty of trying to be a man in dis society. So many expectations, so much pressure. You will see" (186), his father speculates. And Elvis does see, all too 
clearly. In contrast to Obi, who is stuck between worlds that value honor and wealth, Elvis disidentifies from both the patriarchal culture of honor, exemplified by his father, and Western commodity culture, exemplified by Redemption, in which money is "[d]e measure of a man" (187). Unlike Redemption, Elvis is less interested in conspicuous consumption, wealth accumulation, and possessive individualism; he is invested in dancing, a different style of automobility: "something in their lives that they did not have to beg, fight for, or steal" (310). Although Elvis pays steeply for his heroic refusals, the novel rewards him with the possibility of his own redemption, ending with his imminent departure for the United States.

While the novel offers no concrete solutions to the problem of locomotion, it reminds readers that the unsustainable, oil-fueled fantasy of automobility that circulates through the export of American culture is not the only path toward the good life. In contrast to Achebe's urban inhabitants who had "danced once upon a time" (38), Abani's pelvic-thrusting protagonist complicates the notion of Lagos as a dead-end city by moving through and ultimately beyond its inhospitable spaces. We watch as he learns to "read the city, seeing signs not normally visible" (306), signs of lingering neocolonial violence reverberating through the haunted highways.

\section{Automobility and the Global City: Chika Unigwe's On Black Sisters Street}

Whereas GraceLand concludes with the hope that Elvis's escape to America will bring him redemption, the most recent of the three novels, On Black Sisters Street, depicts the impossibility of ever completely escaping Lagos. As if to pick up where GraceLand leaves off, Unigwe's novel follows its four female protagonists as they nominally escape Lagos in pursuit of wealth, learning that they have been sold into prostitution and trapped into a matrix of debt that can only be paid off or absolved in death. The four women-"bound by the same ambition" (151)-come from Lagos to work in Antwerp's red light district (some knowingly, others not), funded by the Lagosian pimp, Oga Deli. In the novel's present, Efe, Joyce, and Ama sit together in their apartment after having found out that their friend Sisi, the novel's central protagonist, has been murdered. As the women try to make sense of Sisi's death, they reflect on what brought them to Lagos, Oga Deli, and Antwerp. Their stories of unanticipated pregnancies, wealthy men, abuse, rape, genocide, and refugee camps are woven together through analepsis, interpolated by Sisi's narrative and through the clues they discover about the mysterious circumstances surrounding her death. 
Similar to the spatiotemporal oscillations of GraceLand, On Black Sisters Street repeatedly jumps between the characters' present in Antwerp in 2006 and analeptic reflections back to Lagos, including the conditions that led them to "Zwartezusterstraat," or Black Sisters Street. Repeatedly referring to Lagos as a place with no future, the novel reveals the naivety of Sisi's fantasy that "Lagos was a city of death, and she was escaping it" (85). While Achebe's novel concludes with the realization that Lagos is a dead-end city in which people get stuck, this is the point of departure for Sisi's narrative-the impetus for enacting an alternative. Just as No Longer at Ease demonstrates the illusory fantasy of urban automobility, Sisi's death testifies to the inescapability of the past, as the characters' fates in Antwerp remain haunted by their histories in Lagos. Despite being fifty years apart, the similar trajectories of Obi and Sisi-both buy into the promise of urban automobility and end up immobilized-testify to the afterlife of colonialism in both opening up and foreclosing this narrative.

The bright lights of Lagos, previously a glowing "globe" emanating "soft light" (Achebe 38) and a "naked lightbulb" (Abani 109), become in Unigwe's novel a prophecy of brightness bestowed on Sisi (then named Chisom) at birth: "Seven days after Chisom was born, at her naming ceremony, a gap-toothed soothsaying neighbor . . . looked deep into her future, and declared to the waiting parents, 'This girl here has a bright future ahead of her ooo. You are very lucky parents 000o'" (210). This foretold bright future is initially interpreted as the promise of automobility, which Sisi inherits from her father, who attempted to traverse a path similar to Obi's:

A civil servant, he had imagined that one day he would be able to buy a car, a secondhand Peugeot 504, but apart from a pay raise in his first year, his salary had remained static even as the prices of everything else rose. He could never afford a car. . . . "How am I ever supposed to buy a car? We thought we were suffering under Abacha. This is worse! At least a military dictatorship did not hide under the cover of democracy. This is worse." He could never buy a car. (77-78)

Her father's recognition of the structural impossibility of obtaining even a modest "secondhand Peugot" indexes the waning fantasy that a good education will inevitably lead to a government job as a civil servant, to a car and a glamorous lifestyle, and to abundant happiness. As with Obi and Elvis, this path to the good life isn't viable for Sisi's father, though she inherits a similar version of it.

Despite her father's failure, Sisi again attempts to materialize the urban promise of automobility. Sisi's family envisions that after 
graduating from the University of Lagos, she will obtain a job at "one of those new banks dotting Lagos like a colony of palm trees. She might even be given a company car, with a company driver to boot. . . . All three laughed at the happy image of a car. (A Ford? A Daewoo? A Peugot? . . .). . . . . 'I don't really care what brand of car I get as long as it gets me to work and back!'" (19). In this example, an education abroad has been replaced by a Nigerian education; a European post (No Longer at Ease) or a job in the United States (GraceLand) has transformed into a job at a global bank in Lagos; and the car that symbolizes these fantasies could come from any number of places (the United States, Korea, or France). Here, Lagos's urban promise has been renewed through its emergence as a global city whose educational institutions, job opportunities, and access to luxury goods are comparable to other wealthy nations. The "new banks" that dot the city "like a colony of palm trees" suggest the neocolonial nature of foreign finance and the way that characters participate in these economic relations through the (now globally interchangeable) fantasy of automobility.

Sisi's family initially believes, "A university education guaranteed a good job. She burned candles when there was a power failure and studied in their light, straining her eyes" (211). This infrastructural power failure is both literal and figurative: despite individual investment and hard work, pursuing the fantasy of automobility in Lagos amounts to merely a "waste of resources." The failure of education to bring about the prosperity it promised is tacitly acknowledged when "[t]here was no longer talk of a company car. Or a company driver" (21). Like a failed engine, life with her boyfriend in Lagos has also stalled: "She knew that he would, like her father, never move beyond where he was. She did not want to be sucked into that life. She imagined her life, one year from now, if she stayed in Lagos. But could she really resort to that? She was not that sort of girl. She turned to go, but her feet felt stuck in the quicksand. They would not move" (40). Sisi refuses to give up on automobility; she follows the prophesy of brightness all the way to Antwerp, which ultimately leads to her job as a sex worker.

Similar to the United States at the end of GraceLand, Antwerp initially seems like it will offer redemption, a place to heal from Lagos's broken promises:

She had watched her dreams and those of people around her scatter every which way. Like having a jar of marbles, glossy with promise, tip and scatter. . . Antwerp was where she would tease out those marbles, gather them and have them fulfill their promise. It was the place to be when your 
dreams died, the place of miracles: a place where dead dreams resurrected and soared and allowed you to catch them and live them. (91)

Here, the language of resurrection describes Antwerp as a clean break from Lagos, though this is precisely the fantasy that On Black Sisters Street undermines. In contrast to Sisi's belief in Antwerp as the city where "dead dreams [are] resurrected," the novel is haunted by Sisi's death, giving the reader a foreboding sense of disenchantment. Unlike Sisi, we see Antwerp from the very beginning as the city that Efe will later describe as a "botched dream" (23).

Sisi's life in Antwerp is motivated by the "happy image of a car," specifically a Japanese Lexus (19). When read alongside the fantasies of the good life that crystallized around a British Morris Oxford in No Longer at Ease and an American Mustang in GraceLand, these examples demonstrate how economic relations of dominance work through imaginative seduction. These automobiles perform the dreamwork of commodity capitalism, through which fantasies of individual automobility eclipse the structural conditions of increasing economic inequality. Lying in bed in Antwerp, Sisi dreams of "[a] Lexus lit up in such splendor that she could not look directly upon it. But she could see the driver. And it was not her. It was being driven by a headless form with a candlewick for a head" (172). This fantasy of a Lexus sustains her investment in the prophecy's promised-and now blinding-brightness. Hours later it enables her to withstand her first sexual encounter as a prostitute: "This is not me. This is not me. A Lexus sparkled in her head" (181). Only later does Sisi realize that the soothsayer hadn't foreseen the bright headlights of a Lexus; rather, she "had seen her in the bright lights of Antwerp. That was her destination. Not, as she had stupidly imagined, a transit route to an infinite betterment of her world. Blue and red lights, like Christmas lights, decorating her window, and she in the middle of all those lights, on display, waiting for buyers to admire and buy" (211). In contrast to the "transit route" of automobility-education, a job with a bank, and gradual progress toward prosperity in Lagos-Sisi realizes that the prophesied brightness turns out to be a reference all along to the tacky display window in Antwerp's red light district.

Sisi's death is presaged by an early remark after deciding to leave Lagos for Antwerp: "she suddenly felt immortal. . . . And it was all thanks to Dele. She owed him her life" (44). During her free time in Antwerp spent pretending to be various wealthy global tourists, she comes to believe in resurrection, that "[s]he was somebody else with a different life. She lived out her fantasies" (220). She is no longer Chisom, the girl from Lagos. In Antwerp, "She could be 
anyone from anywhere" (222). Forgetting her material ties to Lagos and thinking she is out of Oga Deli's reach, she decides to stop paying off her debt, leave the apartment she shares with the other girls, and marry Luc, her boyfriend in Antwerp. In the tragically ironic ending, Sisi is murdered and stuffed into the trunk of a car for attempting to emancipate herself from these debts to Oga Deli.

The fantasy of automobility that crystallizes around Sisi's shiny Lexus runs aground against its material conditions of impossibility: from the moment the women hand over their passports to Madame, they've turned down a one-way street and placed their lives "in someone else's hands" (102). The women trade the mobility of legality for the prospect of wealth in Antwerp. However, flashbacks to the congested, dangerous, and pothole-ridden roads in Lagos-charted through Joyce (formerly, Alek) and Efe's stories-offer metareflections on automobility, revealing that their journeys down a one-way street began long before their lives in Antwerp.

On Black Sisters Street confirms author Peter Chilson's proclamation that "[t]he road in Africa is a place where you realize you have given up the right to survival, put your life in another's hands" (7). Unigwe's novel dramatizes the necronomics of Lagos's informal economy: how "the right to survival" becomes a privilege with unlikely odds. The roads through Lagos, a material example of colonial infrastructure, stage Efe's embodied experience of precarity, feeling the reality that her life is "in another's hands." During her journey on the back of a motorcycle to obtain a third employment, she envisions her own death amid the traffic: "Many times during the ride Efe was sure she was going to be thrown off the back of the bike or that they would ride under a moving truck and that would be the end of her, a mass of bones and flesh flattened under the wheels of a truck carrying crates of soft drink" (68). Her desperation, evident in whispered pleas for the driver to slow down, indexes the lack of control she has over her fate-the antithesis of automobility.

Although Efe survives, the novel also portrays roadside corpses who were not as fortunate, the bodies that make it easy to imagine herself as "a mass of bones and flesh." As in GraceLand, they represent the corporeal afterlife of those who couldn't afford the price of life in Lagos:

On any given day, one was likely to find a corpse abandoned by the roadside, waiting for someone to claim it or for the many vultures that circled the city to devour it. Some of the dead were victims of hit-and-run drivers, most of whom were never found and brought to justice. The majority of the dead . . . were homeless people murdered by those 
who needed them to make money. Apparently, juju made of human blood was the best sort to ensure abundant wealth. (Unigwe 184)

Here, human lives are rendered expendable in order to bring good fortune to others, an embodied enactment of the road's symbolic violence. The unsettling idea that human blood provides the best luck for abundant wealth is also the history of Nigeria, given that many worldwide have garnered their prosperity from Nigerian oil, the would-be lifeblood of the Nigerian people. ${ }^{13}$

Although Lagos and Antwerp ultimately appear more similar than different, both offering access to wealth only through profit on men's desires, the women who remain in Antwerp eventually pay off their debts to Oga Deli and obtain a version of the good life they envision. The fact that Sisi pays with her life indexes the increasingly biopolitical violence of neoliberal globalization, often obscured through its hegemonic discourses of unfettered mobility and worldwide connectedness. And yet, the fantasy of automobility persists. In the moment Sisi dies, her father is back in Lagos, "thinking that when next Sisi called he would mention that at his age and with a child abroad he ought to have a car, and could she not send him one?" (252). With her death, Sisi obtains the ultimate unfettered mobility that her sparkling Lexus stood for, as the final pages track her spirit's journey back to Nigeria.

\section{Reimagining Urbanism in Lagos}

Tracing the trope of automobility while remaining attentive to infrastructure reveals how the characters in these novels both buy into and move beyond inherited colonial investments. The haunted infrastructures that repeatedly foreclose the fantasy of urban automobility suggest that mobility, modernity, urbanism, and colonial violence cannot be disarticulated, as is the case in some social science studies of Lagos. For example, in his work with Harvard's "Project on the City," urban theorist Rem Koolhaas enthusiastically envisions life in Lagos as intense, vital, and dynamic: "A pressure cooker of scarcity, extreme wealth, land pressure, religious fervor, and population explosion, Lagos has cultivated an urbanism that is resilient, material-intensive, decentralized, and congested. Lagos may well be the most radical urbanism extant today, but it is one that works" (718). Included in his chapter on Lagos are sweeping panoramic photographs of highways too distant to see in detail. These novels, however, complicate the perspective of the top-down images of Lagos produced by Koolhaas's urban theory. Instead, they 
depict a city "otherwise fashioned" (Abani, GraceLand 9) from their characters' perspectives on what it feels like to both dwell and sell on the streets-reenacting "the problem of locomotion"-to portray a Lagos still grappling with colonial fallout. Whereas Achebe's novel was penned during (and in response to) Nigeria's transition to indirect rule, the two more recent novels depict neoliberal globalization, implicitly condemning the transnational oil corporations that both rely on and have come to partially displace state power. Although these novels respond to distinct moments of Nigerian postcoloniality, temporal oscillations weave histories of colonialism into their ostensibly postcolonial presents, suggesting "violent" as a missing adjective in Koolhaas's account of Lagos as "resilient, material-intensive, decentralized, and congested."

This pattern of modernization subtended by (neo)colonial dispossession applies to contemporary Lagos. Martin Lukacs's recent article in The Guardian demonstrates how foreign investors, local politicians, and international banks have collaborated to further develop Lagos through the construction of Eko Atlantic, an artificial island whose official purpose is to "head off environmental devastation" and support economic "growth" while in reality it will continue to exacerbate inequality. According to Lukacs the Eko Atlantic will serve the "Nigerian millionaires buying luxury cars and yachts." The first building under construction belongs to a British oil and gas trading company-an ironic testament to the history of multinational oil corporations that haunts these postcolonial novels. When read together, these novels warp the spatiotemporal coordinates by which the erection of urban infrastructure evidences progress. Their critical and creative portraits of Lagos disclose what the rhetoric of urban theory and discourses of development tend to obscure. Indeed, they complicate Koolhaas's celebration of Lagos's style of urbanism as "one that works," by illustrating how the city continues to orient its postcolonial inhabitants down a precarious path marked "ONE WAY."

\section{Notes}

1. Scholars such as Cresswell have theorized the inextricability of mobility and modernity in the context of African cities.

2. My use of "post" in "postcolonial" is informed by Chow, who describes it as "having gone through," "after," and especially "a notion of time that is not linear but constant, marked by events that may be technically finished but that can only be fully understood with consideration of the devastation they left behind" (152). 
3. According to Dawson, cities promise postcolonial characters "liberation from oppressive tradition and clan ties, as well as access to the alluring cultural and material values of the developed world" (19).

4. The extraction of oil wealth began in 1956 and intensified in the following years. See Klieman 3.

5. Woods highlights the role of British colonial rule in poising Nigeria for exploitation by the IMF and World Bank, especially through the development of physical infrastructure rather than productive sectors. See 9.

6. Munro argues that Elvis's travels around Lagos are his (alternative) education. See 49.

7. For a more detailed reading of the novel as a critique of structural adjustment and neoliberal globalization, see Dawson.

8. Nossiter shows that this practice of tire burning has been used in more recent protests in Lagos against cuts to oil subsidies to express popular frustration with a political system in which the country's oil wealth has historically bypassed the majority of Nigerians.

9. Oil figures as blood circulating through the national body, illustrating "the conversion of money into blood" (Apter 50).

10. According to Davis, drivers spend an average of three hours each day grid-locked in traffic, causing them to experiment with dangerous behaviors; see 133. Koolhaas describes these "no-go" traffic jams as sites of both "entrepreneurial activity" and "maximum vulnerability;" see 685.

11. My reading here is indebted to Masquelier's "Road Mythographies: Space, Mobility, and the Historical Imagination in Postcolonial Niger."

12. See Dawson 23 for more on Elvis's self-fashioning.

13. See Apter and Wenzel on the relationship between human blood and oil as lifeblood of the Nigerian national body.

\section{Works Cited}

Abani, Chris. GraceLand. New York: Picador, 2004. . "Lagos: A Pilgrimage in Notations." African Cities Reader. Ed. Ntone Edjabe and Edgar Pieterse. Vlaeberg, So. Afr.: Chimurenga, 2010. 1-8. Web. 13 Aug. 2015.

Abumere, S. I. "Nigeria." Urbanization in Africa: A Handbook. Ed. James D. Tarver. Westport: Greenwood, 1994. 262-78.

Achebe, Chinua. No Longer at Ease. New York: Anchor, 1960.

Apter, Andrew. The Pan-African Nation: Oil and the Spectacle of Culture in Nigeria. Chicago: U of Chicago P, 2005. 
Caminero-Santangelo, Byron. African Fiction and Joseph Conrad: Reading Postcolonial Intertextuality. Albany: State U of New York P, 2004.

Chilson, Peter. Riding the Demon: On the Road in West Africa. Athens: U of Georgia P, 1999.

Chow, Rey. "Between Colonizers: Hong Kong's Colonial Self-Writing in the 1990s." Diaspora 2.2 (1992): 151-70.

Cresswell, Tim. "Towards a Politics of Mobility." African Cities Reader II: Mobilities and Fixtures. Ed. Ntone Edjabe and Edgar Pieterse. Vlaeberg, So. Afr.: Chimurenga, 2011. 159-71. Web. 13 Aug. 2015. Davis, Mike. Planet of Slums. New York: Verso, 2006.

Dawson, Ashley. "Surplus City: Structural Adjustment, Self-Fashioning, and Urban Insurrection in Chris Abani's Graceland." Interventions 11.1 (2009): 16-34.

Gilroy, Paul. Darker than Blue: On the Moral Economies of Black Atlantic Culture. Cambridge: Belknap, 2011.

Klieman, Kairn A. "U.S. Oil Companies, the Nigerian Civil War, and the Origins of Opacity in the Nigerian Oil Industry." Journal of American History 99.1 (2012): 155-65.

Koolhaas, Rem. "Lagos." Mutations. Bordeaux: Arc en Rêve, 2000. 651-719.

Larkin, Brian. Signal and Noise: Media, Infrastructure and Culture in Nigeria. Durham: Duke UP, 2008.

Lukacs, Martin. "New, Privatized African City Heralds Climate Apartheid." The Guardian. Guardian News and Media, 21 Jan. 2014. Web. 13 Aug. 2015.

Masquelier, Adeline. "Road Mythographies: Space, Mobility, and the Historical Imagination in Postcolonial Niger." American Ethnologist 29.4 (2002): 829-56.

Mba, Harold Chike. "The Transport System and Socio-Economic Development." Urban Development in Nigeria. Ed. Robert Taylor. Brookfield: Avebury, 1993. 72-82.

Munro, Ian. "Mapping the Postcolonial Metropolis: Three Recent Novels from Nigeria." Representing Minorities: Studies in Literature and Criticism. Ed. Soumia Boutkhil and Larbi Touaf. Cambridge: Cambridge Scholars, 2008. 38-54.

Nossiter, Adam. "Nigerians Protest Rise in Oil Prices" New York Times. New York Times, 9 Jan. 2012. Web. 13 Aug. 2015.

Otchet, Amy. "Lagos: the Survival of the Determined." UNESCO Courier 52.6 (1999): 22-25.

Unigwe, Chika. On Black Sisters Street. Athens: Ohio UP, 2011.

Wenzel, Jennifer. "Petro-Magic-Realism: Toward a Political Ecology of Nigerian Literature." Postcolonial Studies 9.4 (2006): 449-64.

Woods, Tyron P. "The Gender Entrapment of Neoliberal Development." Genders 55 (2012): n. pag. Web. 1 Sept. 2015. 